Journal of Bangladesh Academy of Sciences, Vol. 35, No. 1, 113-120, 2011

\title{
COMPARATIVE GROWTH ANALYSIS OF TWO VARIETIES OF RICE FOLLOWING NAPHTHALENE ACETIC ACID APPLICATION
}

\author{
NARGIS JAHAN ${ }^{1}$ AND A. M. M GOLAM ADAM \\ Department of Botany, University of Dhaka, Dhaka-1000, Bangladesh
}

\begin{abstract}
A pot experiment showed that 100 and 200 ppm naphthalene acetic acid (NAA) plant height, number of leaves per plant and number of tillers per plant were found to increase due to $100 \mathrm{ppm}$ NAA only in BRRI dhan-29( $\left.\mathrm{V}_{1}\right)$ and varied significantly at 60 DAS. Total dry matter (TDM) was found to increase up to harvest due to both the treatments in $\mathrm{V}_{1}$, whereas, in BRRI dhan-50 $\left(\mathrm{V}_{2}\right)$ also increased at 15 and 30 DAS and the variation was non-significant. There was an increasing tendency in leaf area per plant due to $T_{1}$ treatment in both the varieties except at 45 DAS in $V_{2}$. Significant variations were observed at 15 and 30 DAS only in $V_{1}$. Relative growth rate (RGR) was maximum at early stage of growth and then declined in both the varieties. RGR was significant during 0 to 15 and 45 to 60 DAS in case of $\mathrm{V}_{1}$. Net assimilation rate (NAR) was non-significantly affected and found to increase during 15 to 30 DAS following both the treatments in $V_{1}$, but in $V_{2}$ due to $\mathrm{T}_{2}$ treatment only. Out of the two concentrations $100 \mathrm{ppm}$ NAA produced better stimulation.
\end{abstract}

Key words: Rice, Naphthalene acetic acid, Foliar application, Growth analysis

\section{INTRODUCTION}

In Bangladesh, the demand for rice is augmenting day by day, where the area under rice cultivation is not increasing rather it is reducing. The average yield of rice in Bangladesh is only 4.01 ton/ha (BRRI 2010). This is very poor yield compared to other leading rice growing countries of the world. Lack of modern agricultural practices is the major cause. NAA has proved its potentiality. In appropriate concentration NAA affects the physiological process of a number of plants viz. tomato (Chhonker and Singh 1959), bitter gourd (Jahan and Fattah 1991), lablab bean (Uddin et al. 1994), black gram (Lakshmamma and Rao 1996), chickpea (Karim and Fattah 2007) and cowpea (Ullah et al. 2007). Reports regarding the effects of NAA on cereal plants including rice are available in other countries (Misra and Sahu 1957, Chaudhuri et al. 1980, Grewal and Gill 1986, Muthukumar et al. 2005). But growth and growth attributes of rice in relation to NAA application has not been studied in Bangladesh. Thus an attempt was made to study the effect of NAA on some growth parameters of two varieties of rice.

\footnotetext{
${ }^{1}$ Corresponding author: <imuttaqi@yahoo.com>.
} 


\section{MATERIALS AND METHODS}

During 2009-2010 Boro season a pot experiment was set in the garden of the Department of Botany, University of Dhaka with two varieties of rice BRRI dhan-29 $\left(\mathrm{V}_{1}\right)$ and BRRI dhan-50 $\left(\mathrm{V}_{2}\right)$. BRRI dhan-29 is a high yielding variety and BRRI dhan-50 is an aromatic variety. From the initial analyses of the experimental soil, optimum level of nitrogen and potassium and high level of phosphorus were recorded (Fertilizer Recommendation Guide 2005). Each pot was filled with $9.0 \mathrm{~kg}$ air dried soil mixed with $0.5 \mathrm{~kg}$ cow-dung. The experiment was laid out in a randomized complete block design (RCBD) with three replications. Seeds collected from BRRI, Joydebpur, Gazipur were sterilized with $0.5 \% \mathrm{Ca}(\mathrm{OCl})_{2}$ solution for five min and repeatedly washed in distilled water to remove any trace of $\mathrm{Ca}(\mathrm{OCl})_{2}$. Seeds were sown on November 7, 2009 and seedlings were transplanted to experimental pots at the age of 36 DAS. Before transplanting the seedlings, $2 \mathrm{~g}$ of gypsum was also added in each pot. Initially five seedlings were placed in each pot and thinning was done to keep a healthy seedling per pot. Weeding and irrigation were done as per necessity. Urea as a source of nitrogen was applied twice at the rate of $222 \mathrm{~kg} / \mathrm{ha}$ at 20 and $50 \mathrm{DAT}$. The trial comprised of three foliar treatments: $T_{0}=$ distilled water $\left(\right.$ control), $T_{1}=100 \mathrm{ppm} \mathrm{NAA}$ and $\mathrm{T}_{2}=200 \mathrm{ppm}$ NAA.

Treatments were applied as foliar spray at 57 DAT. Data on plant height, number of leaves per plant, number of tillers per plant, total dry matter, leaf area per plant, relative growth rate (RGR) and net assimilation rate (NAR) were recorded from the age of 15 days after spray (DAS) at an interval of 15 days. Leaf area (LA) was measured by lengthwidth method according to experimental studies at IRRI (1972). RGR and NAR were calculated following the classical growth analysis method (Radford 1967). Data were statistically analyzed and compared by LSD test (Steel and Torrie 1960) at 5\% level of significance.

\section{RESULTS AND DISCUSSION}

Results presented in Fig. 1 showed both increase and decrease in plant height in both the varieties due to both the treatments. Similar results of both increase and decrease in plant height have also been reported by several investigators (Maske et al. 1997 in soybean, Ullah et al. 2007 in cowpea and Akter 2010 in maize). Due to $\mathrm{T}_{1}$ treatment plant height continued to increase up to 60 DAS in $V_{1}$ and was significant at 60 DAS. However, the tallest plants were found from $\mathrm{T}_{2}$ treatment in both the varieties at harvest. 

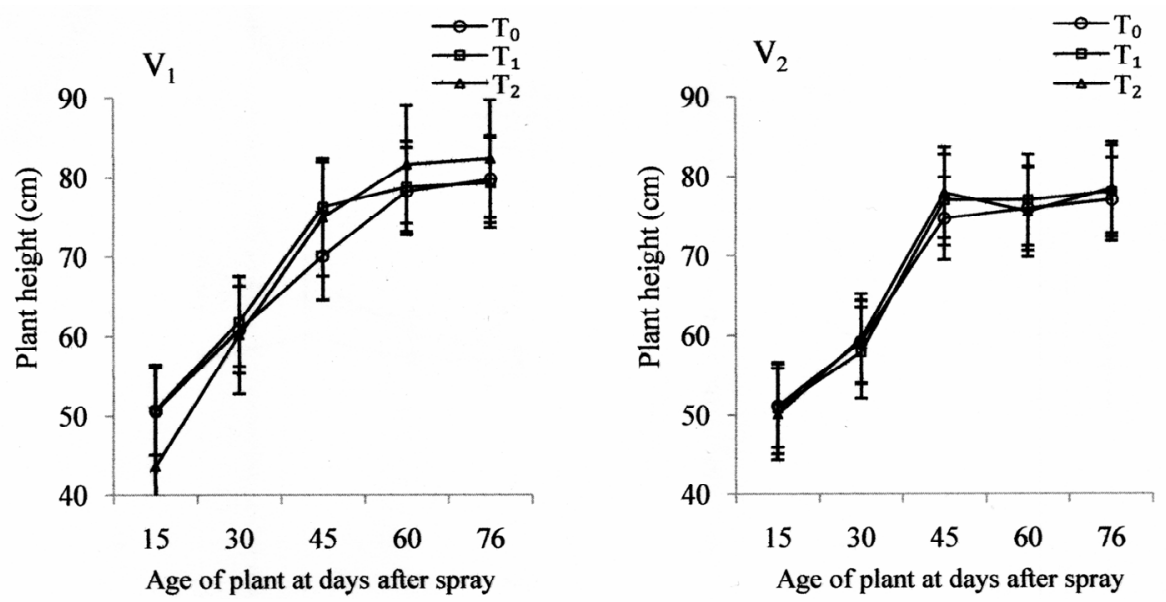

Fig. 1. Effect of NAA on plant height of two varieties of rice at different days after spray (Mean \pm standard error).
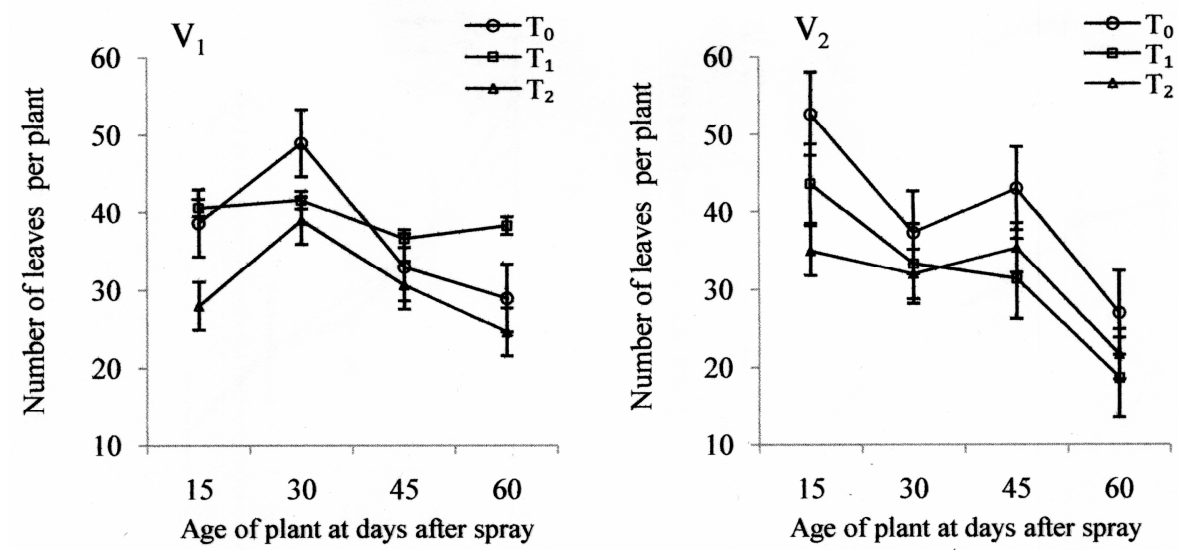

Fig. 2. Effect of NAA on number of leaves per plant of two varieties of rice at different days after spray (Mean \pm standard error).

Number of leaves per plant increased only due to $T_{1}$ treatment at all the ages except at 30 DAS in case of $V_{1}$ and variation was significant at 60 DAS (Fig. 2). The increase in number of leaves due to $\mathrm{T}_{1}$ treatment at 60 DAS was $32.17 \%$ over the control. The increase in leaf number is of vital importance for plants, because of the physiological importance of leaf for photosynthetic activities. The positive effect of NAA on the increases in the number of leaves per plant in rice (Chaudhuri et al. 1980, Bnu and Huang 1980) and wheat and barley (Harsharn and Gill 1985) has been previously reported. In the variety $\mathrm{V}_{2}$, number of leaves per plant decreased following both the treatments and the decrease was significant only at 45 DAS. Number of leaves per plant also decreased due to $\mathrm{T}_{2}$ treatment in $\mathrm{V}_{1}$. Akter (2010) reported both increase and decrease in number of leaves of maize plant. 

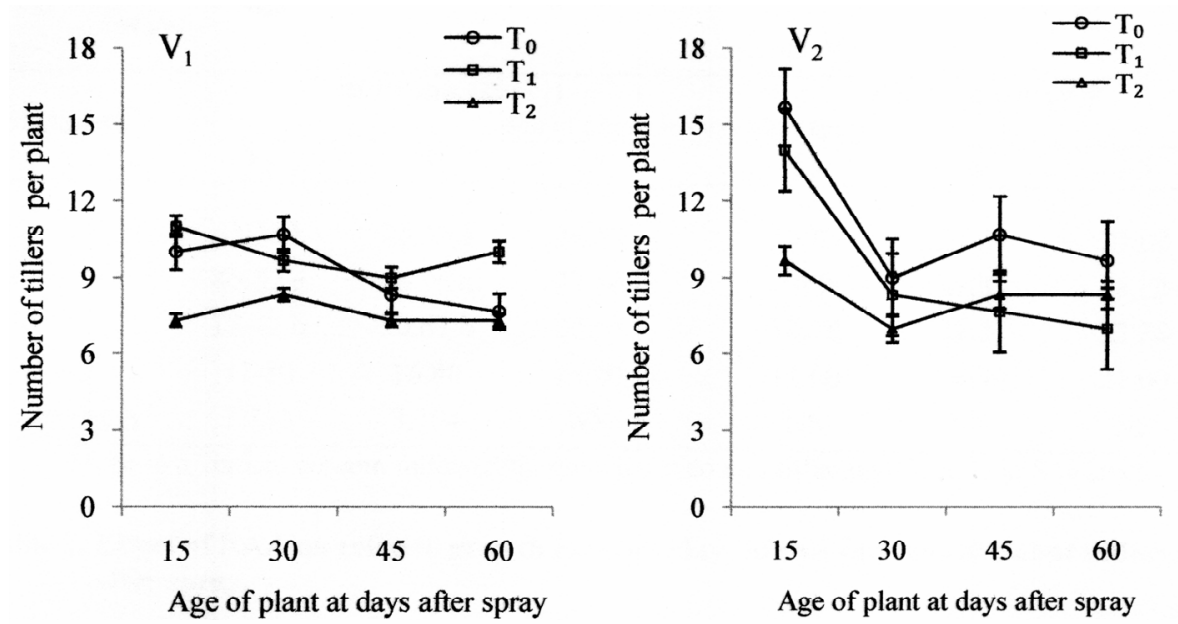

Fig. 3. Effect of NAA on number of tillers per plant of two varieties of rice at different days after spray (Mean \pm Standard Error).
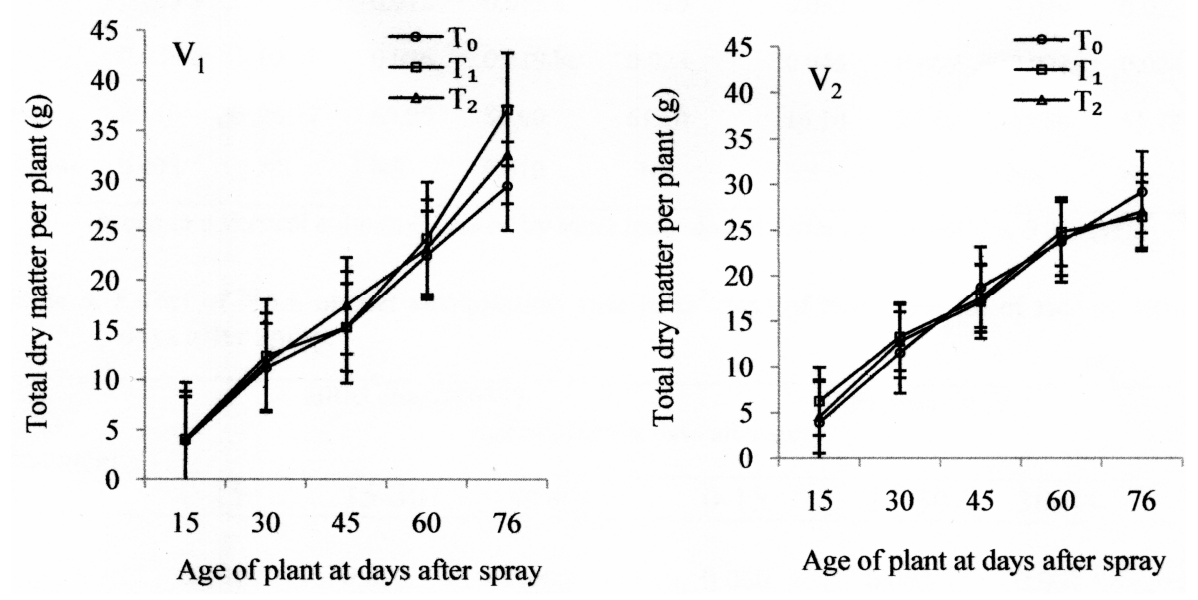

Fig. 4. Effect of NAA on total dry matter per plant of two varieties of rice at different days after spray (Mean \pm Standard Error).

Number of tillers per plant has an indirect effect on yield, but it has a positive effect via the number of panicles per plant. Results in Fig. 3 showed that in $V_{1}$, number of tillers per plant increased at all the ages of growth except 30 DAS due to $T_{1}$ treatment, whereas, decreased due to $T_{2}$ treatment at all the ages. The variation in number of tillers was significant only at 60 DAS and the increase due to $\mathrm{T}_{1}$ was $30.38 \%$ over the control. Chaudhuri et al. (1980) reported about the beneficial effect of NAA spray in rice. Similar results of increases in number of ear bearing tillers following NAA application were reported by Singh and Gill (1985) on wheat and barley and Grewal and Gill (1986) on 
rice. However, in $\mathrm{V}_{2}$ the number of tillers per plant decreased due to both the treatments at all the ages and was significant at 45 DAS due to $T_{1}$ and at 15 and 45 DAS due to $T_{2}$ treatment.

Results indicated that total dry matter (TDM) continued to increase from 15 DAS to harvest following both the treatments in $\mathrm{V}_{1}$. Non-significantly highest dry matter production was obtained from $\mathrm{T}_{1}$ treatment at all ages except at 45 DAS in $\mathrm{V}_{1}$. TDM accumulation was also positively influenced at 15 and 45 DAS due to both the treatments in $V_{1}$ (Fig. 4). Similar results of increased dry matter of plants following NAA treatments have also been reported by many investigators (Patel and Saxena 1994, Ahmed and Tahir 1995, Kalita et al. 1995). Significant increases in dry weight of shoot of maize at harvest were also reported due to 100 and 200ppm NAA application (Akter 2010). However, both increase and decrease in dry matter production were reported by Karim and Fattah (2007) on chickpea and Ullah et al. (2007) on cowpea.

Table 1. Effect of NAA on leaf area $\left(\mathrm{cm}^{2}\right)$ per plant of two varieties of rice at different days after spray.

\begin{tabular}{lllllll}
\hline \multirow{2}{*}{ Treatments } & \multicolumn{5}{c}{ BRRI dhan-29 $\left(\mathrm{V}_{1}\right)$} & \multicolumn{5}{c}{ BRRI dhan-50 $\left(\mathrm{V}_{2}\right)$} \\
\cline { 2 - 7 } & 15 & 30 & 45 & 15 & 30 & 45 \\
& $13.58 \mathrm{~b}$ & $26.50 \mathrm{a}$ & 26.52 & 14.83 & 27.24 & 29.02 \\
$\mathrm{~T}_{0}$ & $15.82 \mathrm{a}$ & $26.96 \mathrm{a}$ & 27.16 & 16.0 & 27.81 & 28.22 \\
$\mathrm{~T}_{1}$ & $12.62 \mathrm{~b}$ & $20.67 \mathrm{~b}$ & 22.55 & 14.78 & 22.21 & 22.28 \\
$\mathrm{~T}_{2}$ & 12.80 & 16.80 & 14.00 & 11.00 & 14.90 & 21.00 \\
$\mathrm{CV}(\%)$ & 1.335 & 3.104 & NS & NS & NS & NS \\
LSD $(0.05)$ &
\end{tabular}

Mean in a vertical column followed by same letter do not differ significantly at $5 \%$ level.

Leaf area varied significantly at 15 and 30 DAS in $V_{1}$, but was not significantly influenced by different treatments in $\mathrm{V}_{2}$. Plants of treatment $\mathrm{T}_{1}$ maintained significantly higher leaf area at 15 DAS only. Leaf area increased progressively from 15 to 45 DAS in both the varieties, but the rate of increase was found maximum for all the treatments during 15 to 30 days of growth period (Table 1). There is evidence that NAA had stimulatory effect on leaf area in wheat and barley (Singh and Gill 1985) and in groundnut (Kelaiya et al. 1991). Grewal and Gill (1986) also reported increased LAI in paddy. Irrespective of the varieties leaf area per plant decreased at all the ages due to $\mathrm{T}_{2}$ treatment. Karim and Fattah (2007) also reported both increase and decrease in LAI of chickpea following NAA application.

RGR was maximum at early stage of growth (15 to 30 DAS). The reason for higher RGR values at the earlier stages of growth is possibly the juvenility of the plants. 
Table 2. Effect of NAA on relative growth rate (g/g/day) of two varieties of rice at different days after spray.

\begin{tabular}{lllllllllll}
\hline Treatments & \multicolumn{1}{c}{ BRRI dhan-29 $\left(\mathrm{V}_{1}\right)$} \\
\cline { 2 - 11 } & \multicolumn{1}{c}{ Age of plants in days after spray } \\
\cline { 2 - 12 } & $0-15$ & $15-30$ & $30-45$ & $45-60$ & $60-76$ & $0-15$ & $15-30$ & $30-45$ & $45-60$ & $60-76$ \\
$\mathrm{~T}_{0}$ & $0.069 \mathrm{a}$ & 0.073 & 0.038 & $0.028 \mathrm{ab}$ & 0.017 & 0.060 & 0.067 & 0.030 & 0.028 & 0.007 \\
$\mathrm{~T}_{1}$ & $0.063 \mathrm{~b}$ & 0.077 & 0.012 & $0.032 \mathrm{a}$ & 0.029 & 0.055 & 0.051 & 0.019 & 0.023 & 0.004 \\
$\mathrm{~T}_{2}$ & $0.039 \mathrm{c}$ & 0.078 & 0.026 & $0.019 \mathrm{bc}$ & 0.023 & 0.045 & 0.069 & 0.021 & 0.024 & 0.008 \\
$\mathrm{CV}(\%)$ & 25.10 & 26.17 & 69.90 & 56.00 & 61.10 & 16.10 & 27.40 & 45.60 & 51.70 & 57.60 \\
LSD $(0.05)$ & 0.002 & NS & NS & 0.010 & NS & NS & NS & NS & NS & NS \\
\hline
\end{tabular}

Mean in a vertical column followed by same letter do not differ significantly at $5 \%$ level.

Haloi and Baldev (1986) also found higher RGR at the initial stages of the growth of chickpea. After that period RGR of all the treatments of both the varieties declined and increased again at 45 - 60 DAS due to $T_{1}$ treatment in both the varieties and also due to $\mathrm{T}_{2}$ only in $\mathrm{V}_{2}$ (Table 2). It has been suggested that the decrease in RGR could be attributed to shading of lower leaves by upper leaves (Thorne 1961). RGR recorded were maximum from $\mathrm{T}_{2}$ treatment in comparison to control during the period of 15 to 30 DAS in both the varieties. RGR increased over the control in the variety $\mathrm{V}_{1}$ during the period of 15 to $30 \mathrm{DAS}$ and at harvest due to both the treatments whereas, in $\mathrm{V}_{2}$ only due to $\mathrm{T}_{2}$. RGR was found relatively higher due to $T_{1}$ in the variety $V_{1}$.

Table 3. Effect of NAA on net assimilation rate $\left(\mathrm{g} / \mathrm{m}^{2} /\right.$ day $)$ of two varieties of rice at different days after spray.

\begin{tabular}{lllcccc}
\hline \multirow{2}{*}{ Treatments } & \multicolumn{5}{c}{ BRRI dhan-29 $\left(\mathrm{V}_{1}\right)$} & \multicolumn{5}{c}{ BRRI dhan-50 $\left(\mathrm{V}_{2}\right)$} \\
\cline { 2 - 7 } & $0-15$ & $15-30$ & $30-45$ & $0-15$ & $15-30$ & $30-45$ \\
& 0.008 & 0.003 & 0.002 & 0.006 & 0.003 & 0.001 \\
$\mathrm{~T}_{0}$ & 0.006 & 0.004 & 0.001 & 0.005 & 0.002 & 0.001 \\
$\mathrm{~T}_{1}$ & 0.004 & 0.005 & 0.001 & 0.004 & 0.004 & 0.001 \\
$\mathrm{~T}_{2}$ & 33.90 & 45.40 & 62.30 & 22.40 & 37.30 & 55.00 \\
$\mathrm{CV}(\%)$ & $\mathrm{NS}$ & $\mathrm{NS}$ & $\mathrm{NS}$ & $\mathrm{NS}$ & $\mathrm{NS}$ & $\mathrm{NS}$ \\
$\mathrm{LSD}(0.05)$ & $\mathrm{NS}$ &
\end{tabular}

Mean in a vertical column followed by same letter do not differ significantly at $5 \%$ level.

NAR represents plant photosynthetic efficiency. NAR of both the varieties showed decreasing tendency towards the later stages of growth (Table 3 ). The decrease in NAR at the later stage of growth could be attributed to shading of lower leaves and increase in the number of older leaves which lost photosynthetic activity (Pandey et al. 1978). NARs varied non-significantly in both the varieties due to both the treatments at different days after spray. NAR were found to increase during 15 - 30 DAS following both the treatments in $\mathrm{V}_{1}$ but in $\mathrm{V}_{2}$ due to $\mathrm{T}_{2}$ treatment only. The highest NAR was recorded at 
0-15 DAS in both the varieties except $\mathrm{T}_{2}$ treatment. Both increase and decrease in NAR were reported by Karim and Fattah (2007) in chickpea following NAA application.

The overall results indicated that NAA has both stimulatory and inhibitory effect on different growth parameters which are in accord with the fact that plant growth regulators at identical concentration can have quite different effects on different plants and even on different organs of the same plant (Ridge 1991). Out of the two concentrations of NAA, 100 ppm NAA produced better stimulations.

\section{REFERENCES}

Ahmed, C. M. S. and M. Tahir. 1995. Effect of growth regulators on the number and volume of tubers in potato. Sarhad J. Agric. 11(5): 575-580.

Akter, R. 2010. Effect of Naphthalene acetic acid (NAA) on growth, physiological and biochemical responses and yield attributes of maize (Zea mays L. var. Pacific 283). M.S. Thesis. Department of Botany, University of Dhaka.

Bnu, R. H. and C. S. Huang. 1980. Effects of the application of plant growth regulators on yield components of early maturing rice. J. Agri. Res. China 29(2): 115-130.

BRRI. 2010. Modern Rice Cultivation, Bangladesh Rice Research Institute. $15^{\text {th }}$ edition. p 5.

Chaudhuri, D., P. Basuchaudhuri and D. K. D. Gupta. 1980. Effect of growth substances on growth and yield of rice. Indian Agriculturist. 24: 169-175.

Chhonkar, V. S. and S. N. Singh. 1959. Effect of Naphthalene acetic acid on growth, quality and yield of tomato. Indian J. Hort. 16(4): 236-242.

Fertilizer Recommendation Guide. 2005. Published by Bangladesh Agriculture Research Council.

Grewal, H. S. and H. S. Gill. 1986. Influence of NAA and Nitrogen on the growth and yield of late planted paddy (Oryza sativa L.). J. Agril. Sci. 106: 37-40.

Harsharn, S. and S.H. Gill. 1985. Effect of foliar spray of NAA on the growth and yield of late sown wheat and barley. Indian J. Ecol. 20(2): 15-21.

Haloi, B. and B. Baldev. 1986. Effect of irrigation on growth attributes in chickpea when grown under different dates of sowing and population pressure. Indian J. Plant Physiol. 29: 14-27.

IRRI, 1972. Annual Report. Int. Rice Res. Inst., Los Banos, Laguna, Philippines. p. 238.

Jahan, N. and Q. A. Fattah. 1991. Effect of foliar treatments of NAA and IBA on reproductive and yield parameters of bitter gourd (Momordica charantia L.). Dhaka Univ. Stud. Part E. Biol. Sci. 6(1): 69-71.

Kalita. P., S. C. Dey and K, Chandra. 1995. Influence of foliar application of phosphorus and Naphthalene acetic acid on nitrogen, dry matter accumulation and yield of green gram. Indian J. Pl. Physiol. 38(3): 197-202.

Karim, M. F. and Q. A. Fattah. 2007. Growth analysis of chickpea cv. Bari chola-6 as affected by foliar spray of growth regulators. Bangladesh J. Bot. 36(2): 105-110.

Kelaiya, V. V., M. G. Jethwa, J. C. Patel and S. G. Sadarea. 1991. Effect of growth regulator and their spraying schedules on groundnut. Indian J. Agron. 36(1): 111-113.

Lakshmamma, P. and I. V. S. Rao. 1996. Response of black gram to shade and naphthalene acetic acid. Indian J. Pl. Physiol. 1(1): 63-64.

Maske, V. G., R. D. Deotale, P. N. Sorte, N. D. Tale and C. N. Chore. 1997. Germination, root, and shoot studies in soybean as influenced by $\mathrm{GA}_{3}$ and NAA. J. Soil and Crops 72(2): 442-449. 
Misra, G. and G. Sahu. 1957. Physiology of growth and reproduction in rice 1. Effect of plant growth substances on an early variety. Bull. Torrey Bot. Club. 86(6): 442-449.

Muthukumar, V. B., K. Velayudham and N. Thavaprakaash. 2005. Growth and yield of baby corn (Zea mays L.) as influenced by PGRs and different time of Nitrogen application. Reasearch $J$. of Agril. and Biol. Sci. 1(4): 303-307.

Pandey, R. K., M. C. Saxene and V. B. Singh. 1978. Effect of moisture stress on growth, yield and yield component of field grown sorghum variety having glossy and non-glossy leaf. Indian Agril. Sci. 53: 428-430.

Patel, I. and O. P. Saxena. 1994. Screening of PGRs for seed treatment in green gram and black gram. Indian J. Plant Physiol. 37(3): 206-208.

Radford, P. J. 1967. Growth analysis formulae: their use and abuse. Crop Sci. 7: 171-175.

Ridge, I. 1991. Plant cells and growth. In: Plant Physiology. The Open University, Hodder and Stoghton. U.K. pp. 225-281.

Singh, H. and H. S. Gill. 1985. Effect of foliar spray of NAA on the growth and yield of late sown wheat and barley. Indian J. Eco. 12: 267-272.

Steel, R. G. D. and J. H. Torrie. 1960. Principles and Procedures of Statistics. McGraw- Hill, New York.

Thorne, G. N. 1961. Effects of age and environment on net assimilation rate of barley. Ann. Bot. 25: 29-38.

Uddin, M. M., M. A. Quadir, A. R. Choudhury and M. K. Choudhury. 1994. Effects of growth regulators on growth and pod of lablab bean grown in summer. Ann. Bangladesh Hort. 14(1): $39-40$.

Ullah, M. J., Q. A. Fatttah and F. Hossain. 2007. Response of growth, yield attributes and yield to the application of KNap and NAA in cowpea (Vigna unguiculata (L.) Walp.). Bangladesh J. Bot. 36(2): 127-132. 